Philosophie ANTIQUE
Philosophie antique

Problèmes, Renaissances, Usages

$18 \mid 2018$

L'athéisme antique

\title{
Atomism and the Worship of Gods
}

On Democritus' ‘Rational' Attitude towards Theology

\section{Christian Vassallo}

\section{OpenEdition}

\section{Journals}

Electronic version

URL: https://journals.openedition.org/philosant/1020

DOI: $10.4000 /$ philosant. 1020

ISSN: 2648-2789

\section{Publisher}

Éditions Vrin

\section{Printed version}

Date of publication: 1 November 2018

Number of pages: 105-125

ISBN: 978-2-7574-2372-1

ISSN: 1634-4561

\section{Electronic reference}

Christian Vassallo, "Atomism and the Worship of Gods", Philosophie antique [Online], 18| 2018, Online since 01 November 2019, connection on 02 December 2022. URL: http://journals.openedition.org/ philosant/1020 ; DOI: https://doi.org/10.4000/philosant.1020

\section{(c) $)(9)$}

Creative Commons - Attribution-NonCommercial-NoDerivatives 4.0 International - CC BY-NC-ND 4.0 https://creativecommons.org/licenses/by-nc-nd/4.0/ 


\section{ATOMISM AND THE WORSHIP OF GODS On Democritus' 'Rational' Attitude towards Theology}

Christian VASSALlO

University of Notre Dame / University of Calabria

christian.vassallo@unical.it

RÉSUMÉ. Cet article réexamine la totalité des témoignages sur la pensée démocritéenne de l'origine du culte divin. Une étude approfondie de ces témoignages nous autorise à affirmer que, dans l'esprit de Démocrite, le culte des dieux ne dérivait pas seulement d'une peur des phénomènes naturels hostiles, mais aussi de la reconnaissance pour les événements favorables à la survie des humains. Il est à présent possible de réinterpréter cette conception selon un point de vue polémique : Démocrite n'aurait pas nié l'existence des dieux, mais plutôt exposé les mécanismes psychologiques qui conduisent les hommes ordinaires à croire dans les dieux traditionnels. Contre la croyance superstitieuse, il démontre, en s'aidant également de la théorie des $\varepsilon$ í $\delta \omega \lambda \alpha$, que les seuls dieux qui existent sont pourvus de la même « raison » que celle à l'œuvre dans la nature et grâce à laquelle les hommes peuvent comprendre ses phénomènes aussi suprenants que variés.

Summary. This paper re-examines the extant testimonia to Democritus' thought on the origin of divine worship. An in-depth study of them allows us to confirm that, in Democritus' view, the worship of the gods derived not only from the fear of adverse natural phenomena, but also from gratitude for events beneficial to human sustenance. It is possible now to reinterpret this conception from a polemical perspective: Democritus would not have denied that the gods exist, but rather exposed the psychological mechanism that leads ordinary men to trust in the traditional gods. Against superstitious faith, he shows, also by means of his eil $\omega \lambda \alpha$ theory, that the only existing gods are provided with the same 'reason' by which nature works and thanks to which men can philosophically understand its various (even astonishing) phenomena.

Philosophie antique, ${ }^{\circ} 18$ (2018), 105-125 



\section{The problem $(s)^{*}$}

So far, all the studies on the theology of the early Atomists have almost unanimously found it impossible to consider Democritus an 'atheist' in the literal sense of the term, viz. a radical denier of the existence of the gods. ${ }^{1}$ Most recently, it has been shown that Democritus had specific theological interests, i.e. that he sought to determine the real nature of the gods, ${ }^{2}$ from both an ontological and causal point of view. ${ }^{3}$ The perspective of this new research represents an important historico-philosophical shift in the study of the thought of the early Atomists. It should suffice to recall that even Eric R. Dodds limited his considerations on Democritus' 'irrational' to some

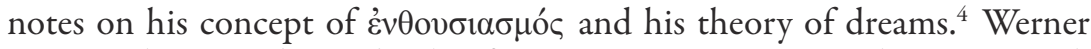
Jaeger, in his turn, devoted only a few pages to Democritus in his major work on the theology of the first Greek thinkers. As a matter of fact, he was still

* I would like to thank Jaap Mansfeld, David Sedley, and the anonimous referees for the useful advice they gave me in revising the manuscript; Jean-Baptiste Gourinat, Gérard Journée, and Rossella Saetta Cottone, for inviting me on 17 December 2016 to give a paper on "Presocratic Doxography in Philodemus' On Piety", within the 2016/2017 séminaire Présocratiques of the Centre Léon Robin, de Recherches sur la Pensée Antique (UMR 8061: CNRS-Sorbonne Université-ENS Ulm). The present article is a revised and extended version of a part of that paper.

1. The various scholars who have conceived of Democritus' gods not as real entities, but only as mere 'guarantees' of the rationality of man and of his inquiry into physical phenomena, are E. Zeller in Zeller \& Mondolfo 1969 p. 264, Wilamowitz-Moellendorff 1931-1932 II, p. 245, and Vlastos 1945. A revival of this approach seems to be found in Drozdek 2007 p. $95-107$.

2. See McGibbon 1965; Eisenberger 1970; Taylor 1999 p. 211-216; Rechenauer 2013 p. 904-906. A status quaestionis on this topic can be found now in Piergiacomi 2017 esp. p. 11-17.

3. On the search for the reasons behind (physical and human) phenomena as the main feature of Democritus' thought, see Morel 1996. On the anthropological implications of the methodology behind this research, see Cole 1967 and infra.

4. Dodds 1959 p. 116-117 and p. 149-150. 
convinced that, unlike Anaxagoras and Diogenes of Apollonia, Democritus had not established his own theology, such as could be systematically framed within his naturalistic philosophy. ${ }^{5}$ By contrast, in accordance with the new trend mentioned above, we are now allowed to consider Democritus' inquiries on the relation between gods and men - ranging from the problem of 'providence ${ }^{6}$ to that of poetic inspiration ${ }^{7}$ and the origin and development of religious ideas in the history of mankind - as 'theological' interests. ${ }^{8}$ Therefore, the causal approach to these tricky questions cannot overshadow the scientific-descriptive approach. On the other hand, the sources at our disposal, while not easy to interpret, seem to attest that Democritus considered the gods real beings, albeit mortal beings who are not concerned with the vicissitudes of mankind.

The atomic constitution of Democritus' gods is not the real subject of this paper, but this problem will be tackled in $\$ 3$ in order to see whether Democritus' arguments on the genesis of the gods could be considered a kind of 'rational' theology in agreement with the physical principles of his thought. In $\$ 2$ I will rather try to analyze in depth the anthropological genesis of the gods according to Democritus and, in particular, to clarify whether - as I believe - his critical theological remarks only concern the gods of popular religion or whether he is speaking about gods or divine beings tout court in a radically polemical way.

\section{Reappraising the sources}

The sole testimonia concerning Democritus' conception of the origin of worship can be found in Sextus Empiricus and Philodemus. What we have here are two sources that are in some way symmetrical. Sextus explicitly mentions Democritus among those philosophers who ascribe our intuition ("'vvot $\alpha$ ) of the gods to the astonishment that derives from the mysterious and therefore frightening phenomena $\left(\pi \alpha \rho \alpha \delta \delta \xi_{\alpha}\right)$ that occur in nature.

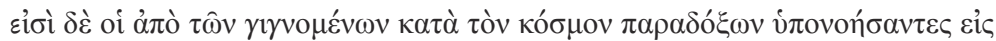

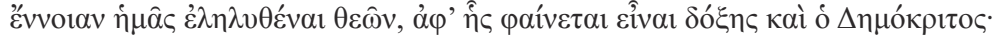

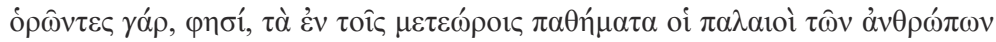

5. Jaeger 1961 p. 281-286.

6. Before Plato's Timaeus (44c) the noun $\pi$ póvora often acquired the meaning of anti-

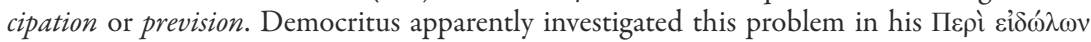

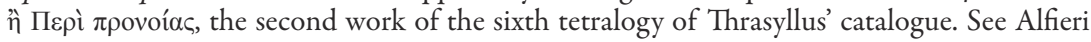
1950 p. 99.

7. Cf. DK 68 B 17-18 (= fr. 574 Luria 2007 [1970] [= Luria]); B 21 (= fr. 575 Luria); B 112 (= fr. 573a Luria); B 129 (= fr. 576 Luria). On this point, see Brancacci 2007 p. 200-205.

8. For this reason, the interpretations that have reduced Democritus' theology to a mere anthropological study of the origin of the idea of the divine seem to be rather incomplete: see, for instance, Gigante \& Indelli 1980 p. 454 and Montano 1984. Indeed, there is no doubt that the 'anthropological' approach plays an important role in Democritus' thought. 


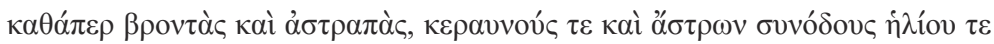

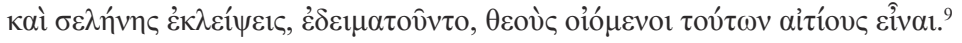

There are some people who think that it was on the basis of the unexpected events that happen in the world that we have come to conceive of gods; Democritus too seems to be of this opinion. For, he says, when ancient men saw what happens in the sky, like thunder, lightning, lightning bolts, conjunctions of stars, eclipses of the sun and moon, they became frightened and thought that gods were the causes of these things. ${ }^{10}$

Indeed, it is controversial to what extent the first part of this testimonium can be considered a genuine piece of evidence for Democritus' theology. The notion of "Evvora of the gods does not properly belong to the lexicon of the early Atomists and should rather be considered a Stoic concept, later reused in sceptical doxography. In this regard, for instance, one could refer to Cleanthes' four reasons to explain why in animis hominum informatas deorum esse notiones. ${ }^{11}$ Anyway, one should consider that the verb ćvvociv is already ubiquitous in Plato and that, provided it is rightly contextualized, Sextus' source is, if anything, more likely to be Epicurean than Stoic. For this reason, the consideration that the noun " tean "does not disqualify the passage from being a testimonium, just from being a verbatim fragment (although there are other reasons for denying that it is a testimonium)." 12 The second part of the passage in question, focused on primitive humans' feelings of fear and frustration towards the forces of nature, deserves in my opinion careful consideration, if for no other reason but the presence of parallel or similar sources (earlier than the $2^{\text {nd }}$ century $\mathrm{AD})$ that help prove in some way the degree of reliability of Sextus' account.

To begin with, Democritus' religious anthropology - as sketched out by the sceptic philosopher - could be compared to Lucretius' Epicurean

9. Sextus M. IX 24 (= DK 68 A 75 [I] = fr. 581 [I] Luria).

10. Transl. by Laks \& Most 2016 p. 249 and 251 (D 207).

11. Cicero, $N D$, II [5] 13-15 (= SVF I 528 [I]; Cf. also Cicero, $N D$, III [7] $16=S V F$ I 528 [II]; the same arguments can be partially found in Chrysippus, SVF II 1009), esp. 14 (third reason): "(...) the awe inspired by lightning, storms, rain, snow, hail, floods, pestilences, earthquakes and occasionally subterranean rumblings, showers of stones and raindrops the colour of blood, also landslips and chasms suddenly opening in the ground, also unnatural monstrosities human and animal, and also the appearance of meteoric lights and what are called by the Greeks 'comets,' and in our language 'long-haired stars,' (...) and the doubling of the sun, (...): all of which alarming portents have suggested to mankind the idea of the existence of some celestial and divine power (quibus exterriti homines vim quandam esse caelestem et divinam suspicati sunt) (...)" (transl. by H. Rackham 1951). On this passage, which (especially for the fourth reason) is suspected to partially depend on Aristotle (see infra), I refer to Mansfeld 1999 p. $470-472$.

12. David N. Sedley per litteras. On Sextus Empiricus' use of Democritus, see, among others, Decleva Caizzi 1980; Sedley 1992; Morel 1996 p. 393-460; Spinelli 1997. 
observations on the origin of civilization..$^{13}$ But, upon a closer inspection, in De rerum natura the list of cosmic and natural phenomena that led men to believe that the gods govern the world is more varied. Lucretius mentions not only lightning, thunder, storm, and earthquakes, but also, more generally (and at the very beginning of his list), the rational order of the movement of the stars and the regular succession of the seasons (praeterea caeli rationes ordine certo / et varia annorum cernebant tempora verti). ${ }^{14}$ Therefore, in Lucretius, the cornerstone of the psychological mechanism that leads primitive men to worship the gods seems to lie not in fear tout court, but in a more general sense of wonder towards those things that are inexplicably greater and stronger than human nature. Such things, mutatis mutandis, were the subject of what, many centuries later, Immanuel Kant considered the dynamisch-Erhabene expressed by nature. On the other hand, in Aristotle's On Philosophy, primitive faith in the gods was said to depend, among other things (viz. the soul and its mechanisms of inspiration and divination), on the contemplation of celestial phenomena, namely the beauty of the sky and

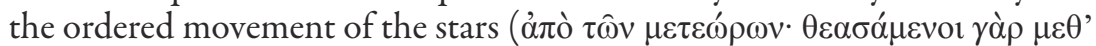

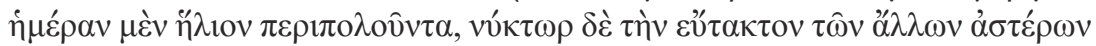

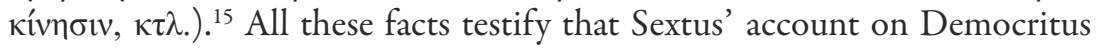
was, at least on this point, rather partial and incomplete. Eduard Norden supposed that the sceptic philosopher took from his source - Posidonius' treatise On Gods - only the negative aspect of Democritean $\delta$ ó $\xi \alpha$, that is to say, the idea that the terrible and awe-inspiring meteorological phenomena induce men to worship gods (only) out of fear. Democritus, instead, would have also referred to phenomena positive and beneficial for human life in order to explain the origin of divine worship not only on the basis of the feeling of fear, but also out of a sense of gratitude (later we will see whether and in what sense his exposition was a polemical one). ${ }^{16}$ This thesis was already accepted by Salomon Luria, ${ }^{17}$ who found a confirmation of it in the aforementioned testimonium by Philodemus. This testimonium is handed

13. Lucretius, V 1183 ff. (= partim fr. 581 [III] Luria = DK 68 A 75 [III]). See Gigante 1957, who identified Lucretius' source as Critias' Sisyphus (on which, see infra). On the relationship between the history of mankind in Democritus, especially through the testimonium by Diodorus Siculus (I 7, 1 = DK 68 B 5 [I] = fr. 558 [II] Luria), and the Epicurean concept of civilization also with reference to theological aspects, see Spoerri 1959 p. 164-211, and Bertelli 1980, with the bibliography cited there.

14. Lucretius, V, 1183-1184.

15. fr. 12a Ross = fr. 947 Gigon (= Sextus, M. IX 20-23), which is most likely the incipit of Book 3 of this Aristotelian dialogue, properly devoted to the study of the divine. See Piergiacomi 2017 p. 18 and n. 22, with the bibliography cited there; Segev 2017 passim.

16. Norden 2002 p. 515-516.

17. Luria 2007 p. 1252-1253. The Russian scholar still relied on Th. Gomperz's old edition of De pietate and on the revised reconstruction of the testimonium in question as proposed by W. Crönert. 
down by the treatise On Piety, especially in the section of that work devoted to the criticism of ancient theological conceptions, from the Presocratics to the early Stoics. This passage can be read in col. 329 Vassallo (= fr. 16 Schober) of PHerc. 1428, a papyrus that transmits the final columns of the large roll containing the work. ${ }^{18}$ Albert Henrichs has argued convincingly that this entire column of PHerc. 1428 refers only to Democritus and that there are good reasons to believe that it transmits not just a witness, but an actual fragment (ipsissima verba) concerning his theological conception. ${ }^{19}$ The new reconstruction which I offer here provides further food for thought on this testimonium, based on a doxographical and, above all, philosophical point of view. ${ }^{20}$

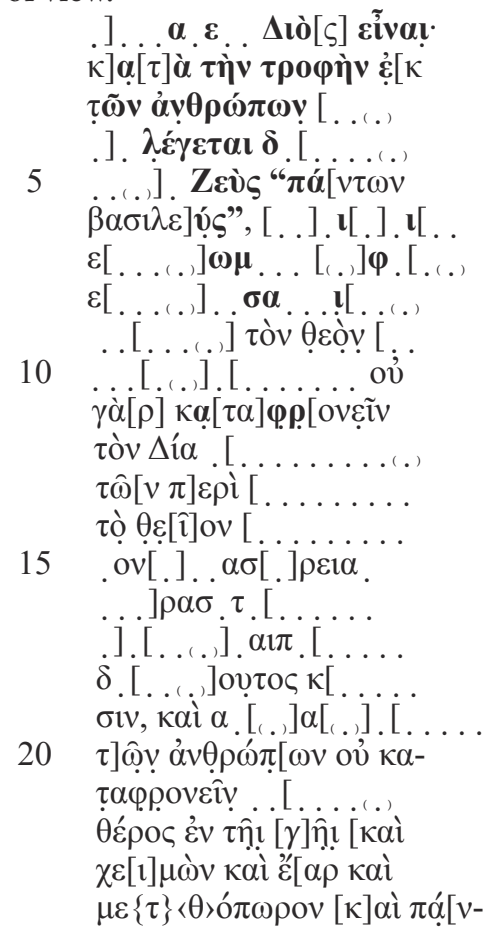

18. On the structure and content of this papyrus, see Vassallo 2017. The passage belongs to the so-called 'second part' of On Piety and has not been published by Obbink 1996.

19. Henrichs 1975 p. 96-106.

20. Conspectus siglorum: Bücheler $=$ Bücheler 1865 p. 529; Crönert $=$ Crönert 1965 p. 130, n. 542; Gigante-Indelli $=$ Gigante $\&$ Indelli 1980 p. 451, n. 3; Gomperz = Gomperz 1866 p. 65-71; Henrichs = Henrichs 1975 p. 94, n. 10; 96; 107; Marcovich = Marcovich 1975; Sauppe $=$ Sauppe 1864 p. 6; Schober $=$ Schober 1988 p. 112-115; Sedley = David N. Sedley per litteras; ${ }^{*}=$ ego. As for the papyrological aspects of the new reconstruction of this fragment (especially the replacement of the initial sovrapposto), I refer to Vassallo 2017 and 2018. 
$\tau \alpha \tau \alpha \hat{\tau} \tau \alpha \stackrel{\alpha}{v}\{01\}\langle\omega>\theta \varepsilon v$ " $\delta \mathrm{t}-$

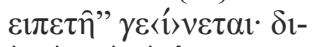
ò $\delta \grave{~ \kappa \alpha i ̀ ~ \tau o ̀ ~} \varepsilon \xi \varepsilon \rho \gamma \alpha-$

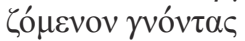

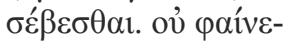

1-20 primum dispexi || 1-2* || 5-6 Cf. DK 68 B 30 || 10 oủ] Sedley: кaì * dub. || 11

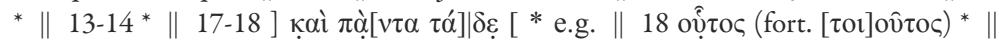

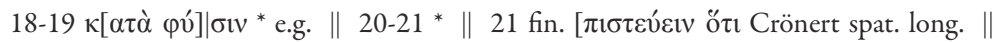


perp. Gomperz in app. dub.: $\dot{\varepsilon} v \tau \alpha \hat{0}[\hat{0}[\theta \alpha$ perp. Marcovich: $\dot{\varepsilon} v \tau \underline{\varepsilon}[\hat{v} \theta \varepsilon v$ perp. Gigante-Indelli

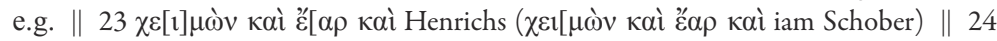

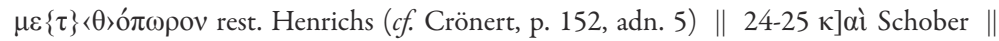
$\pi \alpha{ }_{0}[v] \mid \tau \alpha$ Henrichs $(\pi[\alpha ́ v] \mid \tau \alpha$ iam Gomperz in app.) $\| 25$ óv $\{01\}\langle\omega\rangle \theta \varepsilon v$ Henrichs (iam

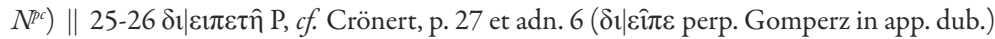

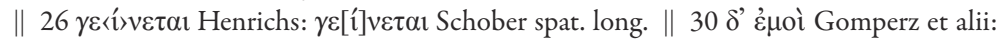



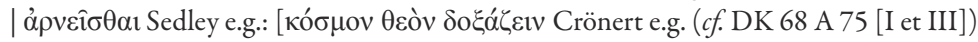

(...) to be of Zeus: according to the care [they believe to receive from him,] by men (...) Zeus (...) is said "king of all things," (...) the god (...) in fact [he (scil. Democritus) says that according to ancient people (?)] Zeus does [not] treat with contempt [humans (?) and] the things concerning [their life (?)] (...) the divine (...) [and all these things (he says)], and (...) to not despise men, [but they think that the annual return of] summer on the earth, and winter and spring and autumn, and all those things, come into being from above "fallen-from-Zeus." That was why, having acknowledged the cause, they worshipped it. But it does not seem to me that Democritus, as some $[$ do, has maintained that $]$ the $\left[\operatorname{god} /\right.$ Zeus does not exist $\left.(?)^{22}\right](\text { continues on })^{23}$

Up until now, only lines 21-31 of this column had been published. As mentioned above, Henrichs tried to demonstrate how those lines contained

21. PHerc. 1428 , cr. 3, col. 329 (= fr. 16) et superp. ibid., sin. sup. col. 328 (= fr. 15) collocatum $=O$ Bodl. Libr. Ms. Gr. Class. c. 5, fol. $1222\left(D, \mathrm{~b}^{\text {inf. }}\right)=N^{\mathrm{pc}}$ fr. $16: N^{\text {ac }}$ fr. $14\left(7^{\text {inf. }}\right)$ $\left[N\right.$ : Apographum Neapolitanum PHerc. $1428, N^{\mathrm{pc}}:$ lectio $\mathrm{N}$ post correctionem / $N^{\text {ac }}$ : lectio $\mathrm{N}$ ante correctionem $]=V H^{2}$ II $5=$ Index Praesocraticorum Philosophorum Herculanensis $(I P P H)$ [in Vassallo 2016] X $51=$ Dox.Graec, p. 535-536 = DK 68 A 75 [II] = fr. 581 [II] Luria = test. 214 Taylor 1999 = test. 128.3 Leszl 2009.

22. It is only an integration exempli gratia to the proposed translation, which would

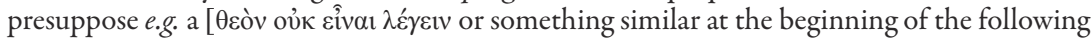
column (the papyrus has a large number of lacunae at that point). But this is obviously the result of the general interpretation of the passage I am giving here.

23. My own translation. 
a quotation of a Democritean fragment rather than simply a paraphrase. The scholar founded his hypothesis above all on a lexical analysis of the passage, and in particular on the use of the following nouns: a) the adverb óv $\omega \theta \varepsilon v$, meaning from on high or from the sky, is not attested in Philodemus, judging from the current research; ${ }^{24}$ b) the adjective $\delta 1 \varepsilon 1 \pi \varepsilon \tau \eta \dot{c}$, which, in this more archaic form meaning fallen/come from Zeus (viz. from the sky), is a Philodemean hapax legomenon, therefore ascribable to the lexicon of the philosopher about whom Philodemus is speaking; ${ }^{25}$ c) the verb $\varepsilon^{\xi} \xi \varepsilon \gamma \alpha$ á $\zeta$ o $\mu \alpha$, which Henrichs wrongly considered not to be attested in Philodemus, ${ }^{26}$ while it is undoubtedly present in two 'ethical' fragments of Democritus. ${ }^{27}$

Personally, I do not believe that these linguistic and lexical elements are enough to demonstrate that we are dealing with a word-for-word quotation of a Democritean fragment. But it is highly probable that, as is the case elsewhere in On Piety and in other Philodemean treatises, the Epicurean philosopher provides the reader with a paraphrase that intermittently quotes words originally used by the author on (or against) whom he is writing. In this specific case, as will be explained shortly, this supposition is proved by the opening lines of the Herculanean passage in question. Before analyzing those lines, we ought to observe that, as a whole, the new reconstruction of the column leads us to make a better informed comparison with the parallel text of Cicero's On the Nature of the Gods, where the Democritean theory of divine simulacra is openly criticized. ${ }^{28}$ Philodemus' testimonium is totally

24. See Vooys 1934-1941, I, p. 34, where three occurences of the adverb, with the Latin meaning of ab initio, can be found. As Henrichs 1975 p. 101 with n. 34-35 observes, the use of this adverb is common in 5th-century Attic Greek, but is attested in Epicurus (Sent. XIII $=$ Sent. Vat. 72; Pyth. 104) as well. A more archaic occurrence can be found in Acusilaus (DK 9 B 40a), as noted by Gigante \& Indelli 1980 p. 452.

25. On the semantic and linguistic complexity of this term, see Humbach 1967, along with the commentary and further literary and bibliographical references in Henrichs 1975 p. 101-102 with n. 37. Another meaning of the noun (shining) in Empedocles' fr. 100, 9 DK, handed down by Aristotle's On Breathing (473b), is pointed out by Gigante \& Indelli 1980 p. 453, n. 13.

26. See Vooys 1934-1941, I, p. 112. Also Henrichs 1975 p. 102 with n. 42 acknowledged the irrelevance (for his demonstrandum) of the use of the neuter with reference to divine action, a usage that is common in all Greek literature and that can therefore be referred not only to Democritus but to other authors as well.

27. DK 68 B 182 (= frs. 35 and 774 Luria) and B 264 (= fr. 604 [III] Luria).

28. Cicero, ND I [12] 29 (= DK 68 A 74 [III]): “(...) Then in what a maze of error is Democritus involved, who at one moment ranks as gods his roving 'images,' at another the substance that emits and radiates these images, and at another again the scientific intelligence of man! (tum imagines earumque circumitus in deorum numerum refert, tum illam naturam quae imagines fundat ac mittat, tum scientiam intellegentiamque nostram.) At the same time his denial of immutability, and therefore of eternity, to everything whatsoever surely involves a repudiation of deity so absolute as to leave no conception of a divine being remaining!" (transl. by H. Rackham 1951). 
different from Cicero's. It deals with the genesis of religious belief among men as an anthropological, and not merely epistemological, process, according to Democritus. Indeed, there is no trace of the $\varepsilon^{\prime} \delta \omega \lambda \alpha$ theory in it, and on the basis of our current knowledge it seems that in no Herculanean text an explicit reference to that theory is to be found ${ }^{29}$ But, as I have mentioned above, it is rather the first (and thus far unpublished) part of the column that provides a further contribution to our understanding of Democritus' conception of the worship of the gods. There we can read the name of Zeus and the context allows us to think that here Philodemus partially quotes Democritus' fr. 30 DK (= fr. 580 Luria). It is the earliest evidence for this fragment in the history of ancient philosophy. In its extended version, it is only known to us through Clement of Alexandria and Eusebius of Caesarea:

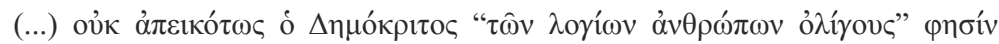

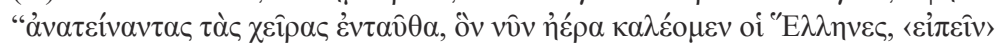

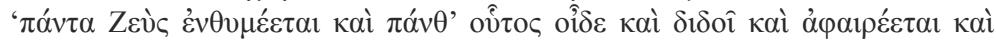

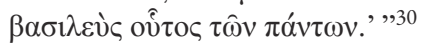

(...) Democritus said, not implausibly, that "a few wise men, lifting their hands toward that place that we Greeks now call the air, <said>, 'Zeus meditates on all things, and he knows all things, gives them, and takes them away, and he is the king of all things." "31

Karl Reinhardt was the first to consider this fragment an elucidation of Democritus' conception of the origin of religion. ${ }^{32}$ But this interpretation of the passage has never been unanimously accepted. Some scholars have used it to prove that Democritus saw the human worship of gods in a favourable light. Within this trend, there have also been those who have highlighted the positive connotation of the adjective $\lambda$ ó $\gamma$ 1or, which according to Hermann Diels should be considered "die Weisen der vorhellenischen Urzeit." 33 Other scholars (the majority) have instead interpreted the fragment as a Democri-

29. In contrast, Piergiacomi (forthcoming) sees in the $\pi \alpha \alpha_{0}[v] \mid \tau \alpha \tau \alpha \hat{\tau} \tau \alpha$ of lines 24-25 a probably (indirect) reference to the simulacra, above all in the light of Sextus, $M$. IX 42 (= fr. 173b Taylor 1999). But the scholar also tries to show that no hint to Democritus' $\varepsilon$ 'i $\delta \omega \lambda \alpha$ theory can be detected in Philodemus' On Poems, Book 4 (PHerc. 207), fr. 10 Janko 2011, as supposed instead by Janko 2011 p. 251, n. 6. For an overview on Philodemus' use of Democritus, see Luciani 2003.

30. Clemens, Protr. 68, 5 (I, 52, 16 Stählin); Strom. V 102, 1 (II 394, 21 Stählin); Eusebius, PE XIII 13, 27 (p. 204, 20 Dindorf = DK 68 B 30 = fr. 580 Luria). Cf. also Hesiod, $O p$. 1-8. Useful remarks on the epithets of Zeus in early Greek poetry can be found in Massetti 2014.

31. Text and translation by Laks \& Most 2016, p. 252-253 (D 210).

32. Reinhardt 1912, p. 510-511, who ascribed the fragment to the Little Cosmology.

33. Diels \& Kranz 1951-1952 II, p. 151 n. See also Jaeger 1961 p. 285-286 and Janko 2008 p. 38. As Alfieri 1936 p. 217, n. 550 recalls, Diels confirmed his opinion in the light of PHerc. 1428, col. 331 Vassallo (= fr. 18 Schober 1988), where Philodemus says that Diogenes of Apollonia praised Homer for having spoken about the divine not according to myth, but 
tean attack on the popular worship of the gods, reading the reference to $\lambda$ ó $\gamma 10$ ironically. ${ }^{34}$ Most recently, there have been some scholars who, while denying that the adjective is ironic, see the fragment as reflecting Democritus' polemics against the conception of God/án $\rho$ held not only by primitive humans, but above all by Diogenes of Apollonia: if so, Democritus would be criticizing those who uphold, philosophically as well as religiously, the divine origin of cosmic phenomena. ${ }^{35}$ Indeed, Philodemus' account seems to me to belong to the tradition that interprets the fragment as a 'rationalist' attack against the worship of the gods. The Epicurean philosopher maintains that the defi-

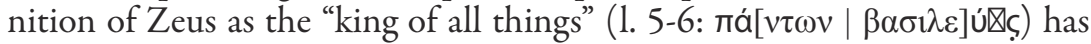
been the consequence of how (according to Democritus) the ancient people began to worship the gods, and in particular Zeus. Based on the observation of natural phenomena, they concluded that Zeus did not treat humans with contempt and finally came to worship him as the source of their sustenance. Therefore, there would be a strong relationship between the human worship of the gods and the satisfaction of the material needs of men. ${ }^{36}$ The unveiling of the real origin of worship is an attack on the common (viz. unphilosophical) conception of divinity, not against the notion of divinity in itself and even less against the divine qua the 'rational principle' of beings and essence

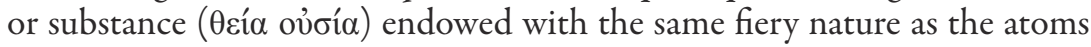
that compose individual souls. ${ }^{37}$ On the other hand, such fiery (or psychical) atoms, which would seem to have been ignored by ancient people, are called

according to the truth, in particular by identifying Zeus with the air. On this piece of evidence, I refer to Laks 2008 p. 129-130 (test. 6 Laks = DK 64 A 8 [I]).

34. The same opinion is expressed, among others, by Luria 2007 p. 722 , who refers to Philodemus, Piet., PHerc. 1428, fr. 15 Schober 1988, where, in his opinion, ảoúvetos would be synonymous with $\lambda$ ófioc. But, as I demonstrate in Vassallo 2018, the old reconstruction by Adolf Schober (and even more so, that of Robert Philippson, which Luria used) is absolutely unreliable. In particular, my new reconstruction shows that in col. 328 Vassallo (= fr. 15 Schober 1988) of the papyrus no reference to the áoúvetor can be detected.

35. Piergiacomi 2017 p. 21, who, albeit cautiously, brings the Democritean work entitled Aitía à ́x́pıo (Diogenes Laertius IX 47) back to this polemical aspect and refers to the frs. 152 DK (= fr. 521 Luria) and $161 \mathrm{DK}$ (= fr. 588 Luria) as well.

36. I adopt this intepretation thanks to the supplement [ov at the end of line 10 by David N. Sedley per litteras. Previously I supposed that lines 10-12 were a comment by Philodemus on the alleged 'atheism' of Democritus, but this does not fit with lines 20-21 and, above all, with the conclusions of the column.

37. This thesis is a much debated one and the sources concerning the question are not so clear. Cf. Cicero, ND I [12] 29 and [43] 120-121a (= DK 68 A 74 [IV]), Xenocrates, fr. 140 Isnardi Parente ${ }^{2}\left(=\right.$ fr. 220 Isnardi Parente ${ }^{1}=$ fr. 21 Heinze) ap. Clemens, Strom. V 88 (= DK 68 A $79=$ fr. 572 Luria), and Augustinus, Ad Diosc. 118, 28 (= frs. 471 and 472a [VII] Luria $=$ deest $\mathrm{DK}$ ). Trying to correct the position of Gilbert 1911 p. 458-478, who hypothesized an ideological link between Democritus and Pythagoreanism on this point (viz. the passage from the divine to the human), Alfieri 1950 p. 102-108 maintains that Democritus, instead, starts from the human to go back up to the divine, and in doing so, highlights the 'rational' 
by Democritus 'divine' and considered by him to be synonymous with the soul and intelligence. ${ }^{38}$ We can infer that the similarity between Democritus' fr. 30 DK and Critias' Sisyphus, posited by some scholars, is rather unlikely. ${ }^{39}$ In the Sisyphus ${ }^{40}$ the gods are portrayed as the invention of a shrewd person

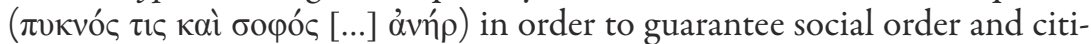
zens' compliance with the laws. Moreover, the invention in question plays only on the fears ( vantageous natural phenomena (e.g. lightning and thunder) and favourable ones (e.g. the beauty of the starry sky and the order of time that gives rhythm to the cosmos). This is the only position in antiquity that can be considered truly or potentially 'atheistic': it combines an anthropological inquiry into the origin of divine worship with the firm belief that the 'divine' is only the

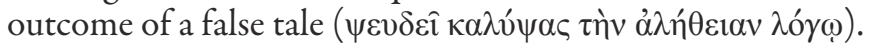

Democritus' criticism against the popular conception of divinity does not follow an 'atheistic' position. According to this perspective, one should relate, in my opinion, Philodemus' testimonium to Prodicus transmitted by PHerc. 1428, col. 333 Vassallo (= fr. 19 Schober) as well. This testimonium presents a structure analogous to that of the second part of the column under consideration. According to Philodemus, Democritus maintained that the worship of the gods was born from the human belief that the cycle of the seasons and all that is useful to human life derive from the sky (namely from Zeus and the other gods) $;^{41}$ however, he would have not inferred the non-existence of the gods from this psychological mechanism. In the same way, Philodemus maintains that Prodicus attacked exclusively the gods that are the object of human faith, not the gods in themselves: the human worship of the gods amounted to nothing but the worshipping of the fruits of the earth and of all that is useful to the material aspects of human life. Therefore, there is good reason to believe that Prodicus, as well as Democritus, identified the origin of the worship of the gods in the natural phenomena not in order to deny the existence of the gods, but rather in order to denounce the inability of

value of the divine. See now the discussion on Democritean 'scientific pampsychism' in Piergiacomi 2017 p. 30-34.

38. Cf. e.g. Aristoteles, De resp. IV 471 b30 (= DK 68 A 106 = frs. 446 and 452 Luria, where other testimonia are also taken into account).

39. See Norden 2002 p. 515; Gigante \& Indelli 1980 p. 452, n. 4; Montano 1984 p. 456-457; Dragona-Monachou 1984 passim; Broadie 1999 p. 222. A different thesis is backed by Piergiacomi 2017 p. 16-17, who argues that Democritus could not consider religion a mere instrumentum regni.

40. DK 88 B 25 (= Sextus, M. IX 54; Aëtius I 7, 2, Dox.Graec., p. 298).

41. Further literary references on the relation between theology and the cycle of the seasons, especially in oracles and sacred hymns, can be found in Henrichs 1975 p. 106, n. 55. 
ordinary men to recognize the true God and his main characteristics. ${ }^{42}$

On the other hand, the second part of Philodemus' account on Democritus (PHerc. 1428, col. 329 Vassallo = fr. 16 Schober) is closely connected to the fragment cited in the first part. This Herculanean piece of evidence represents one of the three texts belonging to Democritus' testimonium A 75 in the Diels-Kranz collection (= fr. 581 Luria), inserted between Sextus' ( $M$. IX 24) and Lucretius' (V 1186 ff.) passages. Although he could not rely on a sound edition of PHerc. 1428, Luria already understood the close link between B 30 and A 75 DK. As a matter of fact, in his collection he published them sequentially, both within the section devoted to the Democritean conception of the origin of the worship of the gods. We can infer that all these testimonia can be reduced to the same logical and argumentative structure. The figure of a Democritus stands out as he attempts: a) to investigate the psychological and anthropological reasons behind the worship of the gods in the history of mankind; and b) to criticize the irrational nature of the feelings of fear and/or gratitude that give rise to worship.

\section{A 'rational' attitude towards theology?}

Humans' perception of the gods, according to Democritus, derive from the stream of images $\left(\varepsilon \varepsilon^{\prime} \delta \omega \lambda \alpha\right)$ that emanate from them. Covering great distances, these images move until they reach the human senses of sight and hearing. On this complex theory we have a large amount of testimonia, ${ }^{43}$ which are difficult to order and to interpret unambiguously. Some scholars have suggested that Democritus' $\varepsilon \iota^{\prime} \delta \omega \lambda \alpha$ theory, instead of having an epistemological function (i.e. to define the nature of the senses), ${ }^{44}$ only has a theological function, because it aims to define atomistic 'demonology. ${ }^{45}$ Also in this case, Sextus Empiricus provides some useful information, which however should be approached with a degree of caution. In Democritus' well-known fr. $166 \mathrm{DK}$ (= fr. 472a [II] Luria) we read as follows:

42. This fact seems to be all the more true in the light of the new readings made of the first part of PHerc. 1428, col. 333 Vassallo (= fr. 19 Schober 1988), where both Prodicus and Diagoras are (most likely) said to believe that the gods exist and have a benevolent nature. See Vassallo 2017 and 2018. In contrast, Mayhew 2011 p. XVII-XVIII, 44-51 (= test. 70-78 Mayhew) and 175-194 opts for a radically atheistic interpretation of Prodicus' thought, but on the basis of not wholly reliable editions of On Piety. See, for instance, my new reconstruction of cols. 347-349 Vassallo (= cols. 1-3 Henrichs) of PHerc. 1428 in this volume (p. 160-164), where the relationship between Prodicus and the Stoic Persaeus is not based on the sophist's 'atheistic' stance. As for Diagoras, Winiarczyk 2016 has demonstrated that it is impossible to consider this author as an 'atheist' stricto sensu. B 166).

43. Cf. the sources collected in fr. 472a Luria (= DK 68 A 33; A 74; A 78-79; B 10a;

44. As maintained by the Peripatetic doxography: Cf., for instance, Aristoteles, Div.Som. 2, $464 \mathrm{a} 5$ (= fr. 475 [I] Luria = deest DK).

45. See A. Capizzi in Zeller \& Mondolfo 1969 p. 279-282. 


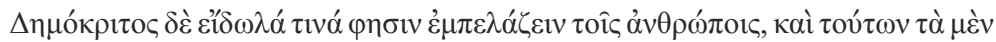

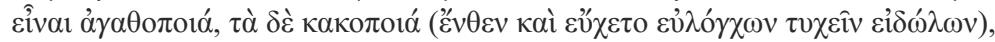

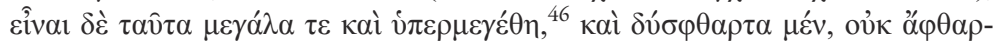

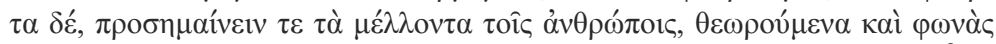

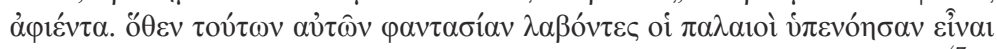

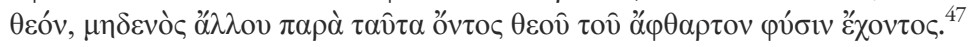

Democritus says that certain images approach people and that of these some do good and others do evil. That is why he expressed the wish to obtain propitious images. These are large and of greater size than normal, and hard to destroy but not indestructible, and they indicate before-hand the future for people when they are observed and utter words. It is on this basis that the ancients, having a representation of these very images, came to suppose that there is a god, given that no other god exists that has an indestructible nature besides these. ${ }^{48}$

If we exclude the reference to $\varphi \alpha v \tau \alpha \sigma i \alpha$, which seems to be another re-use of an Epicurean or Stoic concept, other parallel texts ${ }^{49}$ make this testimonium reliable in its account of Democritus' (images of) gods as extremely large and hard to destroy. The two features in question are the hallmarks of these images, which, on the other hand, also share the common features of all other images. The most complete list of these features can be found in fr. 10 Smith of Diogenes of Oenoanda, which deals with visions $(\varphi \alpha ́ \sigma \mu \alpha \tau \alpha)$ in dreams and criticizes both the Stoics and Democritus on this topic: the Stoics for depriving the visions of something they have and for reducing them to "empty

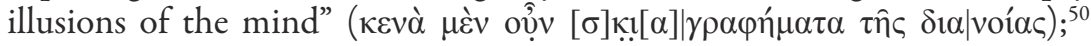
Democritus for endowing them with something which they do not have:

IV

10

ợ

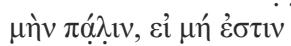

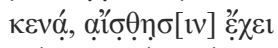

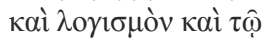

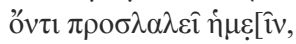

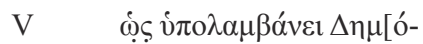

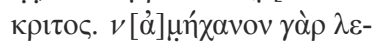

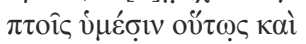

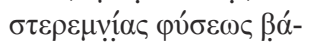

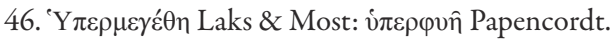

47. Sextus, $M$. IX 19.

48. Text and translation by Laks \& Most 2016 p. 206-207 (D 154).

49. Cf., for instance, Themistius, in Div. Som. 464a5, p. 43, 1 (= fr. 472a [I] Luria = deest DK). For a synoptic comparison between Democritus' doctrine of images as modified in Aristotle's On Divination in Sleep and expounded by Plutarch, see Luria 2007 p. 1164-1167.

50. On the criticism against the Stoics in the Oenoanda Inscription, see now Gourinat 2017. 


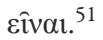

On the other hand, however, if they are not empty, that does not mean that they are sentient and rational and really chat to us, as Democritus supposes; for films which are so subtle and lack the depth of a solid constitution cannot possibly possess these faculties. ${ }^{52}$

If - as commonly stated - Democritus' sleep-visions are produced by images, ${ }^{53}$ we can guess that the former must have the same features as the latter. This fact is already attested in an important testimonium that we find in Plutarch's Convivial Questions, where Democritus is said to have maintained:

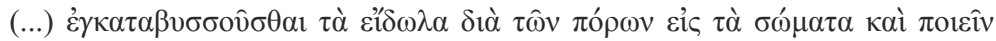

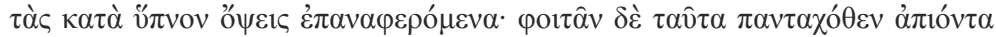

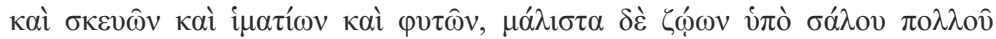

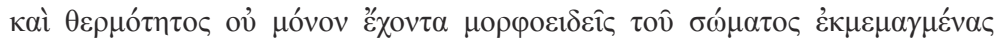

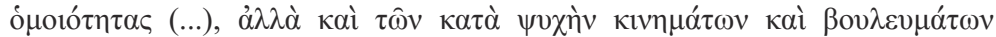



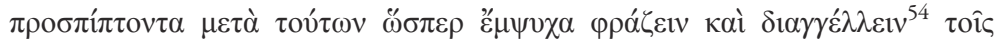

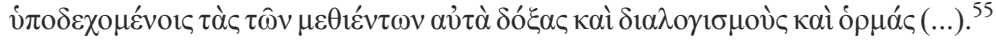

(...) that the images penetrate deeply into bodies by means of their passages and produce visions during sleep when they rise up again. These roam about, coming from everywhere, from equipment, clothes, plants, but especially from living beings, by the effect of intense agitation and heat; they possess not only similarities of form modeled upon the body (...) but they also receive impressions of the motions and desires of each person's soul, of his character traits and passions, which they carry along with them; when they encounter people, accompanied by these things, they speak like living beings and announce to those who receive them the opinions of those who sent them, their considerations, and their impulsions (...). ${ }^{56}$

In this piece of evidence, as Giuseppe Cambiano observes, the likeness of an image to its object concerns the object in its entirety: this fact implies an absolute correspondence between the (qualitative) properties of an animated object and those of the image that it produces. ${ }^{57}$ Now, combining Plutarch's and Diogenes' pieces of evidence, we may infer that rationality

51. Diogenes Oenoandensis, fr. 10 (HK fr. 52 + NF I) IV 10-V 6 Smith. See Smith 1993 p. 450-451; Güremen 2017 p. 197-198.

52. Transl. by Smith 1993 p. 372.

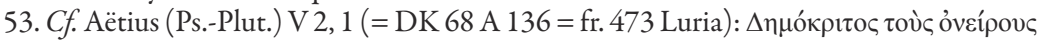

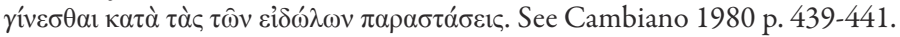

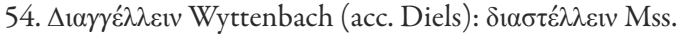

55. Plutarchus, 2uaest. conv. VIII 10, 2, 735A-B (= DK 68 A 77 = fr. 476 Luria).

56. Text and translation by Laks \& Most 2016 p. 204-205 (D 152).

57. Cambiano 1980 p. 442-444. 
(along with sense perception ${ }^{58}$ and reality) is one of the main features of the simulacra of the gods as well, and consequently of the gods themselves, even if irrational living beings too are reached and hit by these simulacra. ${ }^{59}$ Rationality is therefore a common quality of gods, men, and nature. In this regard, it is meaningful that at the end of the Democritean Entstehungsgeschichte of mankind sketched out by Hermippus, ${ }^{60}$ a clear connection between divine

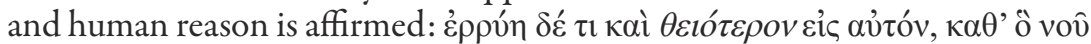

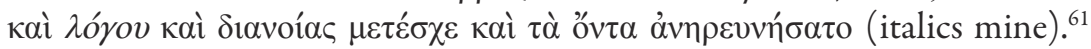
As Luria observes, ${ }^{62}$ intelligence, reason, and intellect represent the 'divine principle' ( $\theta \varepsilon i \hat{0})$ of each human being. Such a principle is strictly linked to human rational supremacy over nature through the crafts ( $\tau \dot{\varepsilon} \chi v \alpha \mathrm{l})$, as already attested in a famous fragment by Ps.-Epicharmus. ${ }^{63}$ But the human control of nature ensured by technical crafts necessarily implies the human knowledge of nature's principles and causes. And this is made possible, in its turn, only by the common structure of pv́øıৎ and human reason. This means that natural (and cosmic) phenomena conceal rational causes that a philosopher is called to discover. ${ }^{64}$ In this sense, and only in this sense, one could speak of Democritus' nature (and cosmos) as something vivified by a kind of 'divine

58. See Sassi 1978 p. 70-76. In this regard, also Diogenes of Oenoanda fr. 43 (NF $12+$ 12) Smith is to be taken into account.

59. Cf. Clemens, Strom. V 88, II, p. 383, 25 Stählin (= DK 68 A $79=$ fr. 572 [II] Luria) and Aëtius, IV 10, 4, Dox.Graec., p. 399 (= DK 68 A 116 = fr. 572 [I] Luria).

60. See Reinhardt 1912.

61. Hermippus, De astrologia (Iohannes Catrares) II 1, 13, p. 33, 15 Kroll \& Viereck 1895 (= DK $60 \mathrm{~B} 5[\mathrm{II}]=$ frs. 515 [II] and 572a [I] Luria). Through this testimonium, Luria 2007

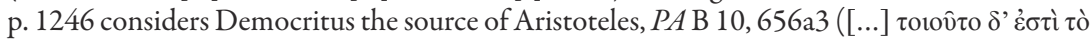

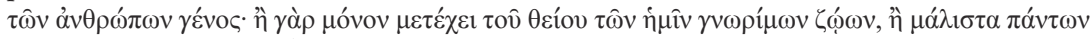

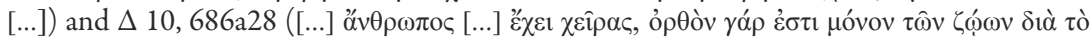

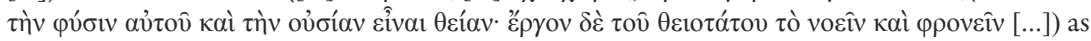
well $(=$ fr. $572 \mathrm{a}[\mathrm{II}]$ Luria $=$ deest $\mathrm{DK})$.

62. Luria 2007 p. 1247.



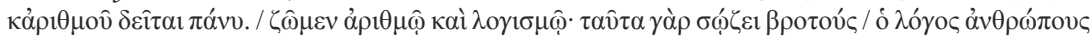

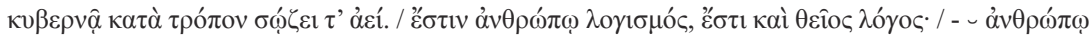

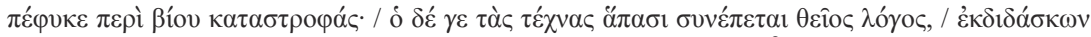

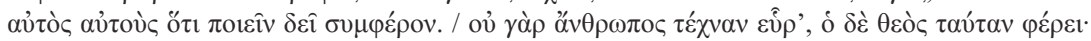

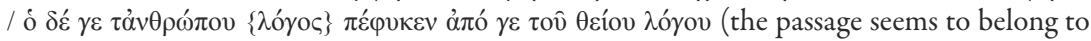
Ps.-Epicharmus', viz. Chrysogonus' Republic: $c f$. DK 23 A 10). On the role of the crafts in Democritus' concept of human progress, see at least DK 68 B 5 [I] (= fr. 558 [II] Luria); B 144 (= fr. 568 Luria); and B 154 (= fr. 559 Luria).

64. Here I am using the term "nature" according to its more extended atomistic meaning. For an in-depth analysis of the polysemy of Democritus' pv́øıc, I refer to Naddaf 1992 passim and Morel 2007 esp. p. 108-109, who notes that "la philosophie naturelle des atomistes ne peut être intégralement définie comme une 'cosmogonie', puisque celle-ci n'est qu'une particularisation de la physique générale des atomes et du vide. Le kosmos ne saurait être l'équivalent de la phusis, qui l'excède logiquement, puisqu'il y a dans le Tout une infinité de mondes." 
principle.' Without a doubt, this last point is not directly inferable from the sources at our disposal. Furthermore, it could be theoretically questioned in the light of the sources concerning Democritus' cosmology. Indeed, Democritus does not describe the cosmogonic process as 'divine,' but makes it the outcome of the mechanical necessity for the atomic whirl that obeys the mere laws of physics: namely, the attraction between similar (animate and inanimate) things based on the timeless whirling motion of the atoms. ${ }^{65}$ However, there are some elements that lead us to postulate a relationship between the action of fiery (or psychic) atoms and celestial phenomena, at least insofar as Democritus seems to insist on the fiery nature of the sky and of the heavenly regions. In this regard, one could recall at least another piece of evidence by

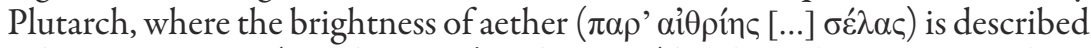
as being $\delta$ เó $\beta \lambda \eta \tau$ also 'holy'); ${ }^{66}$ and another testimonium by Hermippus, where the gods/ daemons coincide with their images and the air (qua physical principle) is

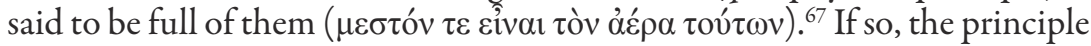
that we have previously considered 'divine' would be nothing but a 'physical' one. In other words, it would be the starting point in any inquiry free of the superstitious prejudices of popular imagery and absolutely in agreement with the structure of the cosmos it attempts to understand. According to this perspective, we might suppose that the $\lambda$ ó $\gamma$ ıo of Democritus' fr. $30 \mathrm{DK}$ are neither 'ancient sages' nor (ironically) 'suckers.' On the contrary, these $\lambda$ ó $\gamma$ io would be more literally men provided 'with reason', in the same way as the gods: that is to say, those who, within their rational investigation of the causes behind physical phenomena, are not frightened by what seems to be incomprehensible and do not lose 'faith' in the rationality and necessity ${ }^{68}$ of the eternal order of all things that derive from those causes.

65. Cf. frs. 288-323 Luria (with their correspondences with the Diels \& Kranz collection). 66. Plutarchus, 2uaest. conv. IV 2, 4, 665F (= DK 68 B 152 = frs. 281 and 415 [II] Luria). But one should take into account that this second term is a controversial addition by $\mathrm{H}$. Diels.

67. Hermippus, De astrologia I 16, 122, p. 26, 13 Kroll \& Viereck 1895 (= DK 68 A 78 $=$ fr. $472 \mathrm{a}[\mathrm{VI}]$ Luria).

68. Cf. Leucippus' fr. 2 DK (= Aëtius I 25, 4, Dox. Graec., p. 321), according to which "nothing happens at random, but everything for a reason and as the effect of necessity" (ov̉ $\delta \dot{\varepsilon} v$

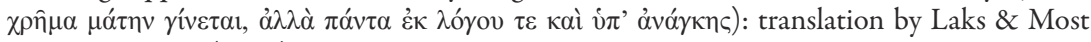
2016 p. 138-139 (D 73). 


\section{BIBLIOGRAPHY}

Alfieri, V. E. 1936 (trad.) : Gli atomisti : Frammenti e testimonianze, Roma, 1936 (Filosofi antichi \& medievali).

- 1950 : « Il concetto del divino in Democrito e in Epicuro », dans V. E. Alfieri \& M. Untersteiner (éd.), Studi di filosofia greca [pubblicazione in onore di Rodolfo Mondolfo per il suo $70^{\circ}$ compleanno], Bari, 1950, p. 85-120 (Biblioteca di cultura moderna, 472).

Bertelli, L. 1980 : « Per le fonti dell'antropologia di Democrito (68 B 5 DK) », dans F. Romano 1980 (éd.), p. 527-532.

BrancaCCI, A. 2007 : « Democritus' mousika », dans A. Brancacci \& P.-M. Morel 2007 (éd.), p. 181-205.

Brancacci, A. \& P.-M. Morel 2007 (éd.) : Democritus : Science, the Arts, and the Care of the Soul: Proceedings of the International Colloquium on Democritus, Paris, 18-20 September 2003, Leiden, 2007 (Philosophia antiqua, 102).

Broadie, S. 1999 : « Rational Theology », dans A. A. Long (éd.), The Cambridge Companion to Early Greek Philosophy, Cambridge-New York, 1999, p. 205-224 (Cambridge Companions to Philosophy).

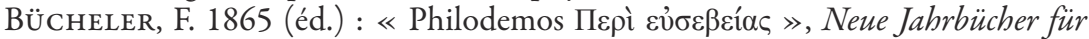
Philologie und Pädagogik, 91 (1865), p. 513-541.

Cambiano, G. 1980 : «Democrito e i sogni », dans F. Romano 1980 (éd.), p. 437-450.

Cole, T. 1967 : Democritus and the Sources of Greek Anthropology, Cleveland, 1967.

CRÖNERT, W. 1965 : Kolotes und Menedemos: Texte und Untersuchungen zur Philosophen- und Literaturgeschichte, Amsterdam, 1965 (Studien zur Palaeographie und Papyruskunde, 6) [1906].

Decleva Caizzi, F. 1980 : Democrito in Sesto Empirico, dans : F. Romano 1980 (éd.), p. 393-410.

Diels, H. \& W. Kranz 1951-1952 (éd.) : Die Fragmente der Vorsokratiker, 1-3, Berlin, 1951-1952.

DodDs, E. R. 1959 : I Greci e l'irrazionale, trad. V. Vacca De Bosis, Firenze, 1959.

Dragona-Monachou, M. 1984 : « Democritus' Psychology of Religion in the Philosophy of Religion of Epicurus $\gg$, dans Proceedings of the $1^{\text {st }}$ International Congress on Democritus (Xanthi, 6-9 October 1983), 2 vol., Xanthi, 1984, II, p. 203-227.

Drozdek, A. 2007 : « Democritus : Renouncing Theology », dans Greek Philosophers as Theologians: The Divine Arche, Aldershot, 2007, p. 95-107.

Eisenberger, H. 1970 : «Demokrits Vorstellung vom Sein und Wirken der Götter », Rheinisches Museum für Philologie, 113 (1970), p. 141-158.

Gigante, M. 1957 : «Lucretius Sisyphum Critiae est imitatus », Dioniso, 20/3-4 (1957), p. 97-98.

Gigante, M. \& G. Indelli 1980 : « Democrito nei Papiri Ercolanesi di Filodemo », dans F. Romano 1980 (éd.), p. 451-466.

Gilbert, O. 1911 : Griechische Religionsphilosophie, Leipzig, 1911.

Gomperz, T. 1866 (éd.) : Philodemus, Über Frömmigkeit, Leipzig, 1866 (Herkulanische Studien, 2). 
Gourinat, J.-B. 2017 : « La critique des stoïciens dans l'inscription d'CEnoanda », dans J. Hammerstaedt, P.-M. Morel \& R. Güremen (éd.), Diogenes of Oinoanda : Epicureanism and Philosophical Debates / Diogène d'CEnoanda : épicurisme et controverses, Leuven, 2017, p. 165-186 (Ancient and Medieval Philosophy. Series 1, 55).

GÜREMEN, R. 2017 : « Diogenes of Oinoanda and the Epicurean Epistemology of Dreams », dans J. Hammerstaedt, P.-M. Morel \& R. Güremen (éd.), Diogenes of Oinoanda : Epicureanism and Philosophical Debates / Diogène d'OEnoanda: épicurisme et controverses, Leuven, 2017, p. 187-206 (Ancient and Medieval Philosophy. Series 1, 55).

Henrichs, A. 1975 : «Two Doxographical Notes : Democritus and Prodicus on Religion », Harvard Studies in Classical Philology, 79 (1975), p. 93-123.

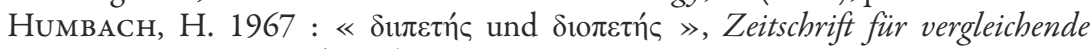
Sprachforschung, 81 (1967), p. 276-283.

JAeger, W. 1961 : La teologia dei primi pensatori greci, trad. E. Pocar, Firenze, 1961 (Il pensiero storico, 45).

Janko, R. 2008 : « Reconstructing (Again) the Opening of the Derveni Papyrus », Zeitschrift für Papyrologie und Epigraphik, 166 (2008), p. 37-51.

- 2011 (éd.) : Philodemus, The Aesthetic Works. 1, 3, On Poems, Books 3-4; with the fragments of Aristotle On Poets, with an unpublished ed. by Cecilia Mangoni, Oxford, 2011 (The Philodemus Translation Project).

Kroll, W. \& P. Viereck 1895 (éd.) : Anonymi christiani Hermippus, De astrologia dialogus, Lipsiae, 1895 (Bibliotheca scriptorum graecorum et romanorum Teubneriana. Auctores graeci).

LAKs, A. 2008 (éd.) : Diogène d'Apollonie, Édition, traduction et commentaire des fragments et témoignages, $2^{\mathrm{e}}$ éd., rev. et augm., Sankt Augustin, 2008 (International Pre-Platonic Studies, 6).

LAKs, A. \& G. W. Most 2016 (éd.) : Early Greek Philosophy, edited and translated, in collaboration with G. Journée and assisted by L. Iribarren \& D. Lévystone, Vol. VII, Later Ionian and Athenian Thinkers, Part 2, 27, Atomists (Leucippus, Democritus), Cambridge (Mass.), 2016 (Loeb Classical Library, 524).

LeszL, W. G. 2009 (éd.) : I primi atomisti : raccolta di testi che riguardano Leucippo e Democrito, Firenze, 2009 (Studi / Accademia Toscana di Scienze e Lettere, La Colombaria, 246).

Luciani, S. 2003 : « Philodème et la "réhabilitation" de Démocrite dans l'épicurisme », dans A. Monet (éd.), Le Jardin romain : épicurisme et poésie à Rome : mélanges offerts à Mayotte Bollack, Villeneuve-d'Ascq, 2003, p. 119-135 (Collection UL3 : travaux et recherches).

LURIA, S. 2007 [1970] (éd.) : Democrito, Raccolta dei frammenti, interpretazione e commentario, introduzione di G. Reale ; bio-bibliografia di S. Luria di Svetlana Maltseva ; traduzione dal russo di A. Krivushina ; traduzione e revisione dei testi greci di D. Fusaro ; realizzazione editoriale, bibliografia, indici e revisione generale di G. Girgenti, Milan, 2007 [1970].

Mansfeld, J. 1999 : «Theology », dans K. Algra, J. Barnes, J. Mansfeld \& M. Schofield (éd.), The Cambridge History of Hellenistic Philosophy, Cambridge, 1999 , p. 452-478. 
Marcovich, M. 1975 : « Democritus on Gods : PHerc. 1428, fr. $16=$ VS 68 A 75 », Zeitschrift für Papyrologie und Epigraphik, 19 (1975), p. 244.

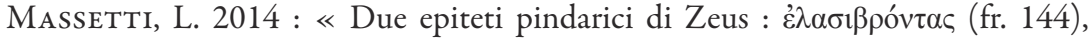

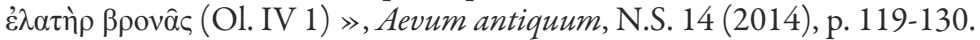

Mayhew, R. 2011 (éd.) : Prodicus the Sophist: Texts, Translations, and Commentary, Oxford, 2011.

McGibion, D. 1965 : « The Religious Thought of Democritus », Hermes, 93 (1965), p. 385-397.

Montano, A. 1984 : « La genèse de la croyance religieuse d'après Démocrite », dans Proceedings of the $1^{\text {st }}$ International Congress on Democritus (Xanthi, 6-9 October 1983), 2 vol., Xanthi, 1984, I, p. 447-468.

Morel, P.-M. 1996 : Démocrite et la recherche des causes, Paris, 1996 (Philosophies antiques).

- 2007 : «Démocrite et l'objet de la philosophie naturelle : à propos des sens de pv́øıৎ chez Démocrite », dans A. Brancacci \& P.-M. Morel 2007 (éd.), p. 105-123.

Naddaf, G. 1992 : L'origine et l'évolution du concept grec de phusis, Lewiston-Queenston-Lampeter, 1992.

Norden, E. 2002 : Agnostos Theos / Dio ignoto : Ricerche sulla storia della forma del discorso religioso, a cura di C. O. Tommasi Moreschini, Brescia, 2002 (Letteratura cristiana antica. Studi) [1913].

Obbink, D. 1996 (éd.) : Philodemus, On Piety, Part I, Critical text with commentary, Oxford, 1996.

Piergiacomi, E. 2017 : Storia delle antiche teologie atomiste, Roma, 2017 (Studi e Ricerche, 64).

- forthcoming : « Democritus' Theory of Eidola in the Herculaneum Papyri : A Reassessment of the Sources », dans C. Vassallo, Presocratics and Papyrological Tradition, Proceedings of the International Workshop held at the University of Trier, 22-24 September 2016, Berlin-Boston, forthcoming.

Rackнам, H. 1951 (trad.) : Cicero, De Natura deorum, Academica, revised and reprinted, London, 1951 (The Loeb Classical Library. Latin Authors, 268).

Rechenauer, G. 2013 : « Leukipp und Demokrit », dans H. Flashar, D. Bremer \& G. Rechenauer (éd.), Die Philosophie der Antike 1, Frühgriechische Philosophie, Basel,2013,2.Halband,p.833-946(GrundrissderGeschichteder Philosophie, 1).

Reinhardt, K. (1912) : « Hekataios von Abdera und Demokrit », Hermes, 47 (1912), p. 492-513.

Romano, F. 1980 (éd.) : Democrito e l'atomismo antico : Atti del Convegno internazionale, Catania 18-21 aprile 1979, Catania, 1980 (Siculorum gymnasium. N.S., 33,1).

Sassi, M. M. 1978 : Le teorie della percezione in Democrito, Firenze, 1978 (Biblioteca di cultura, 145).

Sauppe, H. 1864 (éd.) : Philodemus, Commentatio de Philodemi libro qui fuit de pietate, Goettingae, 1864.

Schober, A. 1988 (éd.) : « Philodemi Depietate, Pars prior », Cronache Ercolanesi, 18 (1988), p. 67-125.

Sedley, D. N. 1992 : « Sextus Empiricus and the Atomist Criteria of Truth », Elenchos, 13 (1992), p. 19-56. 
Segev, M. 2017 : Aristotle on Religion, Cambridge, 2017.

Smith, M. F. 1993 (éd.) : Diogenes of Oinoanda, The Epicurean Inscription, ed. with introd., transl. and notes, Naples, 1993 (La Scuola di Epicuro. Suppl., 1).

Spinelli, E. 1997 : « On Using the Past in Sextus Empiricus : The Case of Democritus », Hyperboreus, 3/1 (1997), p. 151-174.

SpoerRI, W. 1959 : Späthellenistische Berichte über Welt, Kultur und Götter : Untersuchungen zu Diodor von Sizilien, Basel, 1959 (Schweizerische Beiträge zur Altertumswissenschaft, 9).

TAYlor, C. C. W. 1999 (éd.) : The Atomists : Leucippus and Democritus, Fragments : a Text and Translation with a Commentary, Toronto, 1999 (Phoenix. Supplementary volume, 36 ; Phoenix Presocratics, 5).

Vassallo, C. 2016 (éd.): «A Catalogue of the Evidence for Presocratics in the Herculaneum Papyri », Archiv für Papyrusforschung und verwandte Gebiete, 62/1 (2016), p. 78-108.

- 2017 (éd.) : « La 'sezione presocratica' del De pietate di Filodemo : una nuova ricostruzione : Praesocratica Herculanensia X (Parte I) », Archiv für Papyrusforschung und verwandte Gebiete, 63/1 (2017), p. 171-203.

— 2018 (éd.) : « The 'Pre-Socratic Section' of Philodemus' On Piety: A New Reconstruction : Praesocratica Herculanensia X (Part II) », Archiv für Papyrusforschung und verwandte Gebiete, 64/1 (2018), in press.

Vlastos, G. 1945 : «Ethics and Physics in Democritus », Philosophical Review, 54 (1945), p. 578-592.

Vooys, C. J. 1934-1941 : Lexicon Philodemeum, Pars prior, Purmerend, 1934 ; Pars altera, perfecit D. A. van Krevelen, Amsterdam, 1941.

Wilamowitz-Moellendorff, U. von 1931-1932 : Der Glaube der Hellenen, 2 vol., Hildesheim, 1931-1932.

WiniarCZyK, M. 2016 : Diagoras of Melos : A Contribution to the History of Ancient Atheism, translated from Polish by W.Zbirohowski-Koscia, Berlin-Boston, 2016 (Beiträge zur Altertumskunde, 350).

Zeller, E. \& R. Mondolfo 1969 : La filosofia dei Greci nel suo sviluppo storico, Parte I, I Presocratici, Vol. V, Empedocle, Atomisti, Anassagora, a cura di A. Capizzi, trad. di D. Musti, Firenze, 1969 (Il Pensiero storico, 57). 